\title{
Ambiguous Legitimation: Grassroots Roman Catholic Communities in Italy and Ecclesiastical Hierarchies
}

\author{
STEFANIA PALMISANO \\ University of Torino
}

\begin{abstract}
The article deals with the complex and multifaceted relationships arising between the ecclesiastical hierarchy and grassroots Roman Catholic communities, the so-called New Catholic Communities (NCCs), founded in Italy in the wake of the Second Vatican Council and variously inspired by it. Two issues of particular importance in the sociological literature are addressed. The first concerns the criteria with which to construct a typology which can embrace the extreme variety of NCCs in existence today. Adapting a classic distinction drawn by Weber, the paper introduces and discusses a model which distinguishes among communities according to the twofold criteria of ascetic vs. mystical and this-worldly vs. other-worldly. The second issue concerns the recognition that the NCCs are able to obtain from the Catholic Church. It is argued that the negotiations entailed by such recognition are often rendered lengthy and tortuous, both by the controversial nature of the institutional, organizational and liturgical innovations adopted by the Communities and by the existence within the Church of several sources of legitimating authority. Torn between the duty to disavow excessively radical innovations and the desire to prevent open conflict, the ecclesiastical bureaucracy often resorts to forms of ambiguous legitimation, where it is not clear whether the Church's silence amounts to tacit condemnation or tacit approval of the new communities. The paper concludes by exploring the advantages that the NCCs can bring to the Church, and the consequent reasons that induce the relevant authority to abandon its proverbial prudence and grant rapid recognition.
\end{abstract}

Keywords: New Catholic Communities, asceticism, mysticism, this- and other-worldly, innovation, recognition, legitimation

This article concerns the complex and multifaceted relationships that have emerged between the ecclesiastical hierarchy and grassroots Roman Catholic Communities, the so called New Catholic Communities (NCCs), founded in Italy in the wake of the Second Vatican Council and variously inspired by it. The recurrent theme that characterizes these relationships is the way in which and the extent to which these initiatives are legitimized by the hierarchy. The term 'legitimation' is used here to cover a range of possible options: 
from full, official recognition of initiatives encouraged by the hierarchy, to the tacit and at times grudging tolerance of border-line initiatives that for various reasons of prudence the hierarchy does not explicitly condemn.

Before we tackle this issue, we have to consider the way the concept of legitimation has evolved in sociological research in general, and how it has been used in studies on the Catholic Church. The history of this concept includes two contributions of interest with regard to the present article, both viewing legitimation from an institutional point of view. The first, which can also be termed 'early institutionalism', was introduced at the beginning of the twentieth century by Max Weber, while the second emerged at the end of the twentieth century, from the school of new institutionalism. A comparison of the two offers a useful key to comprehending the evolution of our society over the course of a century, and also highlights an element of basic continuity in the use of the concept of legitimation. In the following I describe the main characteristics of these two approaches.

Weber's contribution (1978) lies essentially in the context of the sociology of power. In examining the question of why orders given by a leader are consistently obeyed by his or her followers and/or subordinates, Weber asserts that in order to be obeyed, these orders must appear legitimate. The modes, forms and limitations of exercising power depend on the nature of its legitimation; although this can change over time, what does not change is the fact that when followers/subordinates cease to perceive the orders from their leader as legitimate, the power relationship breaks down. Weber's formulation of legitimation is echoed by organizational scholarship of the present day which examines the legitimation of organizational forms, practices and stratification. Specifically, new institutionalism extends Weber's concept of the power relationship between leader and followers/subordinates to the full array of institutions present in modern society: to appear legitimate, any institution, be it political, financial, cultural, religious or any other kind, must appear to conform to the prevalent norms, beliefs and values of the given society. (Scott \& Meyer 1991; Powell \& DiMaggio 1991.)

Despite their differences, there is an element of continuity between early and new institutionalism, namely that the main focus of the sociological analysis is the continuous, stable functioning of power, whether exercised by political leaders or heads of institutions of any other kind. Legitimation lies at the heart of this. The main focus in the literature on this subject has therefore been on the nature of legitimating processes and the consequences that can arise from a breakdown or a change in their nature. However, in this debate, partly because of Weber's influence, scholarly attention has been 
more focused on the different sources of legitimization than on the concrete ways in which it is manifested. As a consequence, a 'default' space was left for a naive approach, which conceived legitimization as an unequivocal, monocratic, instantaneous, and explicit act. Only recently has this view been disputed by a line of inquiry which emphasizes that legitimization is a gradual process in which it is possible to identify not only different levels of legitimizing authorities, but also different legitimacy statuses granted to the applicants. (Della Fave 1986; Walker et. al. 1986; Riis 1989; Berger et. al., 1998; Zelditch 2001; Johnson et al. 2006.)

Nevertheless, despite this growing literature, very limited attention has as yet been devoted to the actions implemented by specific institutions, such as ecclesiastical authorities, as agents in the legitimation of initiatives launched within their sphere of control. In other words, if we admit the existence of a dual relationship between institutions and the social contexts in which they are set - in the sense that the former draw legitimation from their context and in turn lend legitimation to other initiatives in that setting - it can be noted that studies to date have focused almost exclusively on the former relationship, neglecting the latter.

This imbalance is particularly evident in sociological analyses of the Roman Catholic Church following the Second Vatican Council. Apart from the work of Séguy $(1984)$, Wittberg $(1996 ; 2007)$ and Hervieu-Léger (2000) who, as we shall see, have addressed the issue of the legitimation of new forms of religious life, in almost all of the literature on the subject the prevailing focus is on the foundations of the legitimation of the work of the Church, specifically the ecclesiastical hierarchy (Dinges 1987; Seidler \& Meyer 1989; Ebaugh 1991). Thus what is still almost entirely missing is an empirical analysis of the means, forms, limitations and ambiguities of the legitimization processes implemented by the ecclesiastical hierarchy with regard to grassroots initiatives that develop within or without the Church. In an era of heated debate on the meaning of the work of the Church in the modern world, it is equally instructive, I argue, to explore the ways and conditions in which the relationship between the ecclesiastical hierarchy and these initiatives develop.

In this paper, my purpose is to show how different types of NCCs, introducing different kinds of innovation in respect to traditional religious life, deal with various problems of ecclesiastical legitimation. Examining the forms of canonical recognition that the NCCs are able to obtain from the Church, I argue that such recognition often involves lengthy and tortuous negotiations; they are made so both by the controversial nature of 
the institutional, organizational and liturgical innovations adopted by the NCCs, and by the existence within the Church of several sources of legitimating authority. Torn between the duty to disavow excessively radical innovations and the desire to prevent open conflicts, the ecclesiastical bureaucracy often resorts to forms of ambiguous legitimation, where it is not clear whether the Church's silence amounts to tacit condemnation or tacit approval of the NCCs.

The article is structured as follows. In section 2, I describe the main characteristics of NCCs, illustrating my findings from a multiple case study of ten NCCs based in Piedmont, North-Western Italy. In section 3, I introduce a typology aimed at representing the extreme variety of the NCCs in existence today: adapting a classic distinction drawn by Weber, this typology distinguishes among NCCs according to the twofold criteria of asceticism vs. mysticism and this-worldly vs. other-worldly. In section 4, I show how the different types of NCCs, bringing different kinds of innovation, deal with different problems of legitimation. I conclude by exploring the advantages that the NCCs can bring to the Church, and the consequent reasons that induce the authorities to abandon their proverbial prudence and grant rapid recognition. The analysis of the variables at work in the subtle negotiations between communities and authority, which induce the latter to accelerate recognition, or even to recognize ecclesiastically questionable communities, raises a number of questions for further research.

\section{New Catholic Communities in Piedmont. The Results of Field Research}

Vatican Council II was an institutional watershed in the religious history of the last century. In its endeavor to re-actualize the identity of the Roman Catholic Church and to mediate between religion and emerging cultural demands, it engendered profound change in the life and organization of the ecclesiastical world (Abbott 1966). In particular, it produced widespread conflict between innovative reformers and conservative resistance, both within Church ranks and among the faithful. Within the panorama of the consecrated life, this contrast cannot be interpreted simplistically as an opposition between old and new institutions; it follows far more complicated lines. Both among institutions that existed before the Council and those founded after it, there are some that implemented processes of renewal and reform, and others that took a more conservative tack. My interest centers on NCCs founded post-Council that reinvigorated religious life in keeping with the spirit of Vatican II. These are groups of people - of whom at 
least some have taken vows ${ }^{1}$ - who have come together in an association to pursue an ideal of religious life, engaging in specific activities as outlined by a mission that constitutes the community's raison d'être and is expressed in its Rule (cf. Table 1).

Unlike traditional communities, the NCCs are not religious orders because they are not recognized by the Holy See. Their founders want to be separate from pre-existing orders, so these communities fall outside the jurisdictional orbit of the Church's institutions. Their autonomy has enabled them to introduce important innovations that render the organization of monastic life more flexible and better suited to the contemporary age. However, these innovations often provoke distrust among ecclesiastical authorities. The main validation for NCCs usually springs from the trust they place in their life project, rather then the institutional recognition of the Roman Catholic Church. Nevertheless, some NCCs - above all those who feel they are called to an evangelization mission - apply for approval, even if unwillingly. When this happens, the ecclesiastical authorities verify their authenticity, applying an evaluation procedure that usually takes many years and whose outcome is unpredictable. As we shall see, for purposes of recognition the NCCs and the authorities engage in negotiations rendered long and tortuous by the controversial nature of the innovations introduced by the former, and by the cautious stance adopted by the latter.

The NCCs are not only highly varied, but also extremely numerous, both in the United States and Europe - where they are especially common in France, Spain and Italy (Blasi \& Zimmerman 2004; Diotallevi 2001; Landron 2004; Baudouin \& Portier 2002; Rocca 2002; Roldàn 2009; Wittberg 1996); thus a comprehensive examination of their full extent is not possible. I therefore concluded that the only feasible route was to carry out an in-depth investigation of a limited number of NCCs which I know - directly or by repute - are pursuing different missions. Specifically, I chose the research strategy of theory building from multiple cases ${ }^{2}$ (Eisenhardt \& Graebner 2007), examining ten NCCs based in Piedmont, North-Western Italy, since the study providing the basis for this article was commissioned by a foun-

1 According to canon law, laypeople are 'non-clergy': in other words, all those who have not taken holy orders (i.e. deacons, priests or bishops). Laypeople may have taken vows of chastity, poverty and obedience, in which case they are consecrated (cf. Canon 573). Leaving aside the distinctions of canon law, the term 'laypeople' is here restricted to those who are not consecrated, i.e. have not taken vows.

2 The multiple case study approach was well suited to the tasks, first, of generating descriptive and analytical material in an unexplored field; second, of identifying generic elements common to different organizations (Eisenhardt \& Graebner 2007; Yin 1994). 
dation in Turin which promotes efforts to achieve a greater understanding of the local area. ${ }^{3}$ As two of the communities we investigated have their mother houses outside Piedmont, I studied their branches in this region.

Fieldwork was carried out in two stages. In the first stage (2007-2008), thanks to the help of privileged observers (scholars, bishops, priests, monks, members of NCCs etc.), I contacted and visited eighteen NCCs, interviewed superiors and their associates, and examined documents produced by the communities (histories, rules and byelaws in particular). ${ }^{4}$ I conducted a total of around thirty structured interviews and more than one hundred hours of participant observation. ${ }^{5}$ In the second stage (2009-2010), I carried out case studies of ten out of the eighteen NCCs, selected on the basis of the innovations they had introduced and of their relationship with the ecclesiastical authority. Table 1 sets out essential information on these ten NCCs, stating denomination, year of foundation, the founder's status, the group's composition, its mission, its tradition of reference, and its form of canonical recognition. Finally, in order to study the processes of canonical recognition and legitimation, I interviewed the bishops of the five dioceses in which the communities examined are located.

\section{A Typology of NCCs}

If the processes of canonical recognition and the problems of ecclesiastical legitimation differ according to the type of NCC, we need to determine how they might be differentiated from one another. I have used two conceptual axes to construct a typology of NCCs, both of Weberian origin (1978): the relationship with God, which may be ascetic or mystical, and the relationship with the world, which may be one of detachment or engagement. ${ }^{6}$

3 Study funded by the Fondazione Cassa di Risparmio di Torino as part of the Progetto Alfieri.

4 The Communities examined in the first stage included: Comunità di Montecroce, Fraternità di Nazareth, Monaci Apostolici Diocesani, Monastery of Bose, Monastery of Cumiana, Fratelli Contemplativi, Monastery of San Biagio, Ricostruttori nella preghiera, Comunità Cenacolo, Movimento Contemplativo Missionario Charles de Foucauld, Sermig, Convento Famiglia, Associazione Maria Accogliente, Koinonia Giovanni Battista, Comunità di Gesù, Comunità Magnificat, Comunità San Paolo, Comunità Eucaristia.

5 In-depth interviews provided us with the words of founding members as to their own personal experience of God and as to how this experience influenced their choices in the definition of the Community's mission. Participant observation at worship events enabled us to analyze the religious practices (liturgies) in which those experiences have been realized.

6 Christiano, Swatos and Kivisto $(2008,307)$ note that 'asceticism-mysticism' is a typology of soteriology, or the means by which people understand themselves to enter into or remain in a valid relationship with the Beyond. From the viewpoint of the practitioners, it is thus the kind of things they ought to do in order to be in such a relationship. 
These two axes intersect to generate four ideal types of NCCs (Table 1): 1) Other-Worldly Ascetic; 2) This-Worldly Ascetic; 3) Other-Worldly Mystical; 4) This-Worldly Mystical. It is important to remember, however, that all ideal types are heuristic concepts that attempt to capture the essence of an empirical case or development, not to encompass all empirical cases. Hence even the most ascetic Community will contain mystical elements and vice versa.

Before going into the details of these four ideal types, the meaning of the two conceptual axes that define them must be explained.

\section{Ascetic or Mystical Relationship with God.}

Weber made the distinction between ascetic and mystical relationships with God when he compared Western and Eastern religions. Seen in terms of an ideal-typical model, the distinctive features of asceticism are action towards a purpose and the rationalization of all ethical conduct, which translates into a methodical self-discipline (Kalberg 2001). According to Weber, the ascetic feels that he is 'an instrument of God' $(1978$ I, 545) in the sense that he comprehensively systematizes his own personal patterning of life to achieve God's will. Mysticism, in contrast, has the opposite attitude towards action: the mystic seeks 'rest' in God, and replaces activity with the static enjoyment of a possession of the divine as a unio mystica with it. In Weber's view, the mystic sees himself not as an instrument but as a 'vessel'. He tends towards an emotional view of religion and yearns for 'a substantial feeling of God': the feeling of a real entrance of the divine into the soul of the believer 'characterized by its passive search for the fulfillment of the yearning for rest in God'. (Weber 1978 I, 546.)

Weber also notes that in Western societies it is unusual for an individual to become a mystic, owing to the omnipotent and omniscient character of the distant, monotheistic God, which precludes the immersion in the supernatural realm sought by the mystic believer. According to scholars within the sociology of religion (Bord \& Faulkner 1983; Csordas 2001; Marzano 2009; Neitz 1987; Pace 1983; Roldàn 2009; Christiano et al. 2008), to some extent this is changing because post-Vatican II Roman Catholicism is finding aspects of mysticism that were dormant within the Christian tradition.

On the basis of the literature mentioned above, I argue that NCCs fit this typology: the ascetic ones are committed to methodical action in order to achieve God's will by developing their members' spiritual growth in addition to changing the world; the mystical, conversely, are committed to 
reducing action in order to experience God without mediation. Compared to the classic Weberian tradition, the novelty of many recently appearing mystical communities is that, as we shall see, this direct experience of God is usually revealed through collective ecstasy, miraculous appearances and thaumaturgical events. The Catholic Charismatic Communities which I have studied can be included in this mystical type. They arose as part of a worldwide movement known as the Catholic Charismatic Movement, which in turn sprang from Protestant neo-Pentecostalism (Anderson 2010; Csordas 1997; Wilkinson \& Althouse 2010). Its members have rediscovered the Holy Spirit, and have adapted the theology of the 'Baptism of the Spirit' (also known as 'effusion of the spirit' ${ }^{7}$ from the Pentecostalists. They believe that the Spirit is active in the modern world and that it manifests itself in tangible signs or 'charisms' (Poloma 1989). These include 'gifts', such as speaking in tongues, prophecy, states of trance, miracle healings, and liberation from demonic influence - all experiences which can be referred to mystical soteriology (Christiano et al. 2008).

\section{Relationship of Engagement or Flight from the World}

According to Weber, both asceticism and mysticism may be either otherworldly or this-worldly. In other-worldly asceticism, the ascetic rejects the world because he considers it a distraction from the 'total concentration on acting in the task of salvation' (Weber 1978 II, 133). Weber's empirical example of this type was the medieval Catholic monk. The this-worldly ascetic sees himself as an instrument chosen by God, and must operate 'within the institutions of the world but in opposition to them' (1978 II, 133), in order to vivify and transform it to match ascetic ideals. Here Weber refers to the Puritans.

In other-worldly mysticism, the contemplative flight from the world leads away from action, away from thought, to a total divestiture of whatever recalls the world to us in any way. The mystic is led 'to reach an interior state that is savoured like possession of the divine'. At moments of maximum exaltation, the mystic speaks a language that is neither usual nor ordinary, but is a sign of possession of a special knowledge. For Weber, it is Buddhism that most closely fits this type. However, the consequence of mystical contemplation is not always flight from the world. For the mystic, as for the ascetic, orientation towards the world can translate into an adaptation to its

7 The effusion of the spirit is a sort of new baptism (or 'renewal' of the original pledge) which marks the believer's entry into full membership of the charismatic organization (Marzano 2009). 
institutions. Unlike the ascetic, however, the this-worldly mystic reduces his action to a minimum. He recognizes his vocation to live in the world, but 'incognito', in a permanent 'state of rupture' with it. From this he would like to flee, taking refuge in the peace of intimacy with God. (Weber 1978 II, 236-7.) Here Weber had Classical Hinduism in mind.

In the following analysis I have divided both ascetic and mystical NCCs on the basis of their orientation with regard to the world. The otherworldly communities 'withdraw within themselves' to meditate and pray, though in this withdrawal they often attract the 'world', in the sense of inspiring other people who wish to join them in seeking spiritual support and refreshment; the worldly communities, in contrast, 'come out of themselves' to bring the Gospel, to offer material aid to the needy, or merely to proselytize. A brief description of each community enables me to present the innovations they have introduced in the traditional religious life. I next describe the NCCs studied allocated to each ideal type (Figure 1); it should be borne in mind that in referring to a specific NCC I am not saying that it necessarily coincides entirely with that type, merely that it tends toward it.

\section{Otherworldly Ascetic Communities}

The mission of these NCCs is to help their members achieve spiritual perfection in monastic life by means of a methodical conduct of life based on prayer, labor and silence, and governed by a rule of renunciation (of food, sleep, companionship, comfort etc.), in more or less radical detachment from the world. Three of the NCCs I surveyed belong to this type:

a. Comunità di Montecroce. Founded in 1973 in a small country town near Turin by a priest with extensive experience of parish work and Third World missions. Soon after reaching forty, he felt the need to abandon active life for a period of hermitage. For two years he lived alone in an abandoned church, until a couple of people asked permission to live with him. These requests were interpreted as a 'divine sign' in answer to his prayers to have a community, and he agreed willingly. Thus was formed the first nucleus of the Community (two men and a woman) which took pre-Benedictine monasticism $^{8}$ as its inspiration. Over time the Community defined its

8 If in the practice of chastity we can see the first element of material discipline among the earliest groups of ascetics within the Christian community, and in Hermitism a methodical spiritual discipline by means of introspection and discernment, when we arrive at the Cenobitic community and their practice of obedience, at least on the sociological level we may begin to speak of a true community of consecrated life (Abbruzzese 1995, 61). 
mission as teaching the lectio divina and attracted some forty people, who, however, live on their own rather than with the monks. Their membership in the Community takes the form of participation in the prayer walk that the monks organize free of charge every year, and of taking turns praying in each other's houses.

b. Fraternità dei monaci apostolici diocesani. Founded in 1995 in Turin by a priest of French origin and a layman. Torn between the active and the contemplative life, and after a variety of experience, they happened upon the Fraternité des moînes apostoliques de Saint Jean-de-Malte in France. This Fraternité consists of five Dominican friars who in 1977 were given permission to leave the friary to create a new form of monastic life in the parish, dependent on the diocesan bishop. The two men interpreted this discovery, which put an end to their wanderings, as 'the finger of God'. Returning to Turin, they asked the bishop if they could do the same. With his approval, the first nucleus of the Community moved into a small house assigned to them, annexed to the church, with the mission of pursuing monasticism in the parish according to the rule propounded by the French model. The laypeople who gravitate around the Community thus do not have the status of members, but simply that of parishioners. Currently, the Community consists of three priests, one of whom is the parish priest. To retain the monastic dimension (in other words, detachment from the world in silence, prayer and study) and allow for part-time work outside the parish, they have divided management and pastoral activities among themselves, and take turns celebrating liturgical functions (except on Sundays, when all three are present).

c. Fraternità di Nazareth. Founded in 1978 in a small country town near Turin by a priest and a nun. Though actively involved in their congregations, they decided to leave them when they received what they interpreted as a heavenly invitation, in the form of the urgings of several young people, including two engaged couples, to set up a new Community. The initial plan was for all of the members to live separately in pursuit of their own vocations, and to meet on weekends. While they were looking for a place to meet, however, an event occurred that the founders saw as providential: the accidental discovery of an abandoned chapel in the woods, with a small building attached to it, suggested that God's plan for them was a Cenobitic monastic life (cf. note 8). Remodeling the Community began as soon as the group moved to the site. Thus was formed the first nucleus, whose organization was inspired by the Benedictine, Carthusian and Franciscan monastic traditions, as well as by the lives of the saints. After a few years, 
the Community defined its mission as family catechesis. Over time, fiftyodd people have joined the group, some interested in living in matrimony, others in the consecrated life. The Community has thus developed two legally and financially independent branches: one for the monastic life, the other for the lay one.

\section{Worldly Ascetic Communities}

The mission of these NCCs is to provide assistance or missionary work among the more vulnerable segments of society, according to a Rule of Life which, unlike the otherworldly communities, entails a life of active engagement in the 'world'. Another three of the ten NCCs I surveyed belong to this type:

a. Cenacolo. Founded in 1983 in a small country town near Turin by a nun, who after years of work in a congregation decided to help marginalized young people (drug addicts, alcoholics, the mentally disturbed etc.); for this purpose, she obtained from the Municipality a tumble-down farmhouse on a hill. She interpreted this donation as a sign of God's will, and thus withdrew temporarily from the congregation and moved to the farmhouse with another nun and a schoolteacher friend. When the young people they were helping exceeded fifty, the sisters decided to abandon the congregation entirely and devote all their time to the Community. In the meantime, the Community expanded: on the one hand a dozen volunteers offered part-time services, and several of them then decided to take vows; on the other, around twenty rehabilitated former patients decided to live full-time in the community as 'permanent volunteers'. Several of them formed families, which still live in the Community. Under the guidance of the founder, some of these volunteers have opened small fraternities around the world, where they help abandoned children, drug addicts and alcoholics. There are now 57 such fraternities in Italy, the rest of Europe, South America and the United States.

b. Movimento Contemplativo Missionario Charles De Foucauld. Established in Cuneo in the early seventies, by a priest with lengthy and intensive experience as founder and director of a community to help war orphans, the Città dei Ragazzi. When growing economic difficulties and Italy's changing social scene made it seem as if this work no longer had a future, he interpreted this adversity as divine assistance and decided to change the Community's mission to carrying out missionary work in developing countries. The number of members rose rapidly to over one hundred; under his guidance, they 
opened small fraternities around the world to help the poor, the sick, and abandoned children. There are now 47 of these fraternities scattered around Europe, Africa, Asia and Latin America. At the end of the eighties, the Città dei Ragazzi was converted into a home for ex-prostitutes, immigrants and AIDS victims. At the same time, the Community serves as a spiritual center, offering prayer classes and summer retreats for laypeople, especially the young.

c. Sermig (Servizio Missionario Giovani). Founded in 1964 in Turin by a layman (a bank clerk), his wife and several friends. The small group started by organizing events - exhibitions, concerts, fairs and so forth - to raise money for missionaries in the third world. With the addition of another fifteen members, the desire arose to form a community. The group thus began to look for a suitable site. When they came across an abandoned arsenal in the center of town, they took the discovery as a divine sign. The group asked the municipality if they could take over part of the building to turn it into a community, with the mission of combating hunger and working for peace. Only after repeated applications to the local authorities and the intervention of prominent politicians was the group, twenty years after its foundation, able to take possession of the arsenal, which they renamed the Arsenale della Pace (Arsenal of Peace) and restored, together with volunteers from around Italy. They began by providing immigrants, drug addicts and AIDS victims with medical care and a place to stay during the day and at night, and by offering classes for young people in art restoration, music, crafts etc.. They also set up nursery schools. Their work on the local scene was extended to development projects in third world countries. These activities led to the establishment of another two Arsenals, one in Brazil and the other in Jordan.

\section{Otherworldly Mystic Communities}

Only one of the mystical NCCs I investigated can be classified as otherworldly. As the mother house of this community is in the Veneto, I studied the branch opened a couple of years ago in Piedmont, near Biella. The name of the community is Koinonia Giovanni Battista, founded in 1979 in the province of Vicenza by an Argentine priest with previous experience of community life. After having an 'effusion of the Spirit' in charismatic circles, he considered founding a cloistered monastic community. But a succession of prophetic images, which he attributes to God and in which God showed him 'a promised land' in which the sick are healed and the dead are brought back to life, caused him to change his mind. He moved to the prophesied place, a small village in the upper Veneto. Here he lived 
for three years in solitude, until a local woman, known for her prophetic gifts, revealed to him that she had received a message from God in which he was named as her pastor, and exhorted him to found 'a house of prayer open to all'. In the meantime his reputation as a healer grew, many people began to attend his masses, and three young people asked to live with him. Shortly thereafter they took vows. Thus was formed the first nucleus of the Community. During the week, as the founder had decided, they lived strictly cloistered, between prayer and farm work; on Sundays they opened their doors to thousands of the faithful, who flocked there for the healing masses he celebrated and to apply to him for miracles. These appeals, which he saw as being in line with the prophetic images that he believed to be divinely inspired, encouraged him to change the Community's mission. From its original vocation of prayer in detachment from the world, the Community converted to worldly engagement with evangelization. For this purpose, it opened schools of evangelization that offer courses to fee-paying students (how to use charisms to convert, how to free oneself from spells, how to achieve economic success etc.) that have spread rapidly in many European and South American countries. Around one hundred candidates wishing to join the community arrived from these schools, leading the founder to plan a further expansion. Though this expansion took place, it was not spearheaded by the founder, who was sentenced to three years of imprisonment for fraud, following a complaint filed by a follower whom he had promised, in return for a large sum of money, to heal a relative with cancer. This event exacerbated his relationship - already strained - with the Italian episcopate. He was prohibited from exercising his ministry, and the recognition of public association of the faithful granted to the community a few years earlier was revoked. He was obliged to step down, but the community, under the guidance of his closest associates, and with the support of several Eastern European bishops, was able to grow despite these setbacks. It became international in scale and was organized as a federation of communities, with legal headquarters in the Czech Republic. The communities (which are called 'oases') now number 28: seven in Italy, sixteen elsewhere in Europe (including eight in Eastern Europe), two in the United States and two in South America. There are 169 consecrated members (76 brothers and 93 sisters) and over 4000 lay associates, who support the Community economically with one-tenth of their salaries, i.e. 'tithes'. 


\section{Worldly Mystic Communities}

Three of the NCCs I investigated fall into this category. They were founded as part of the Renewal in the Spirit (Rns), the leading organization in Italy's charismatic movement. These communities share the mission of evangelization, although in different ways according to the specific 'charism' each community wants to develop. As distinct from the otherworldly mystical NCCs described above, members of worldly mystical NCCs do not live 'under the same roof' but meet on specific occasions only.

1) Comunità di Gesù. Established in 1978 in Turin by two laypeople, a man and a woman, who were in charge of an Rns group. During a prayer meeting, a priest, also belonging to the Rns, told them he had received a prophetic image: God is angry because they have too long ignored his call to form a community. The two thus decided to start a Community, together with three other people. Soon some thirty members formed a group, which meets regularly to pray. Almost ten years after it was founded, the Community felt the need for a more radical form of engagement. The mission was changed to evangelization, with a preference for 'charisms' connected with physical and spiritual healing or 'liberations' (a form of exorcism). To this end, the Community organizes monthly healing masses in a downtown chapel. The unexpected influx of believers seeking help or healing obliged the leaders to seek more spacious accommodation; despite the doubts of some of the local clergy, the group obtained permission to use a larger church. After almost ten years, the Community's leaders suspended its activities. The main factor which led to this decision was the prejudice felt by the local church and public against the Community ('a bunch of faithhealers'). Today the Community no longer organizes public prayers in the city's churches, but continues to hold 'healing meetings' for its members. The latter now number over 200, in sixteen brotherhoods in various locations around Italy: nine in Piedmont, three in Latium, one in Sardinia, two in Tuscany and one in Emilia Romagna.

2) Comunità San Paolo. Started in 1997 in a small rural town near Vercelli, by a laywoman who had been in charge of an Rns group. After holding positions of responsibility in the ranks of the charismatic renewal for nearly twenty years, she felt the need for a deeper commitment. She considered joining the Comunità di Gesù, but two prophetic events made her change her mind. In a prayer meeting with other charismatic groups, a member of Koinonia prophesized that she herself would soon lead a community. Somewhat later, on a similar occasion, a priest confirmed this revelation. A couple of years later, three people, including a priest, told her they wanted 
to participate in the community project. Under her guidance, they began to meet one evening a week to pray. Thus was formed the first nucleus of the Community which over time defined its mission as evangelizing, with particular emphasis on the epiphany - 'Making Christ known with the power of the Holy Spirit' - and hence the practice of charisms. To this end, the Community organized healing prayer meetings, masses of intercession for the ill, pilgrimages to Marian sites, and so on. A dozen or so people joined, nearly all of them resident in the same area. Today the community has twelve members.

3) Comunità Magnificat. Founded in 1977 near Perugia (here again, I investigated the Piedmont branch of the community, located close to Turin) by a layman, with years of experience in charismatic circles. During a prayer, he received what he interpreted as prophetic words, 'with Jesus, on Jesus build', accompanied by the image of a trowel. Inspired by this urging, he invited friends and students (he is a university professor) to pray together one evening a week. This was the first nucleus of the Community, which with the passing years has adopted the mission of evangelizing. Today it has over 500 members (including twelve consecrated laypeople and seven priests), divided among fourteen brotherhoods in Italy: one in Piedmont, one in Lombardy, one in Trentino, seven in the Marches, one in Latium, one in Apulia, one in Sicily, and one in Molise.

\section{The Authentication Process and Ambiguous Legitimization}

Some innovations introduced by the NCCs described in the previous section have aroused the distrust of the Roman Catholic Church, which is concerned about the consequences in terms of disorder, scandal or abuses. The Church recommends caution in officially recognizing a new community; when one of these asks the ecclesiastical authorities for approval, it is therefore subjected to a long process of inspection in order to appraise its 'authenticity', first of all by examining its Rule of Life. According to the 1983 Code of Canon Law, if ecclesiastical problems do not arise the authorities should support the community so that it can grow and develop. To this end gestures are offered (blessings, public praise, conferral of posts, offers of money and so on), which even in the absence of official recognition legitimate the community's work and enhance its consensus.

This principle suggests that in the sociological study of the internal practices of the Church we need to distinguish between recognition (or authentication) and legitimization. 'Recognition' refers to a formal and 
unequivocal act, performed by a canonical authority created for that specific purpose. 'Legitimization' refers to a larger and more complex set of relationships between the ecclesiastical authorities and communities, which gradually leads to their de facto acceptance, even if this is not confirmed by formal recognition. It is important to stress that there is no necessary nexus between recognition and legitimization; they follow a different logic and at different speeds. There exist communities with low recognition and high legitimization: in other words, a lack of canonical recognition does not necessarily mean that a community does not enjoy esteem, benevolence, consensus and/ informal support within the Church.

In order to understand the crucial role performed by the linkage between legitimization and recognition in the Catholic world, we need to bear in mind certain differences in behavior between the Catholic Church and the Protestant Churches. Whilst the latter prefer eccentric groups to opt for scission, the Catholic Church, with its more centralized authority, has always sought, as far as possible, to keep these groups within its aegis by 'domesticating' them (Wittberg 1997; 2007). While on one hand this policy enables the Church to verify the authenticity of new religious communities, granting or refusing them recognition, on the other it generates constant and embarrassing problems of negotiation, mediation and compromise. This gives rise to a complex interplay between indulgence and recalcitrance, which leads to 'ambiguous legitimization': a grey area in which it is difficult to decide whether the Church's silence expresses cautious support or covert disapproval. Viewed as a continuum, this 'ambiguous legitimation' can be said to have tacit approval at one extreme and reticent disapproval at the other; the large number of 'intermediate' positions range from cautious support through benevolent silence to increasingly marked reservation and reticence. The main source of ambiguity is the contrast between the logic of action adopted by religious movements and that applied by the ecclesiastical authority. The unpredictability of the former recalls the gospel verse, 'The wind bloweth where it listeth, and thou hearest the sound thereof, but canst not tell whence it cometh and whither it goeth: so is every one that is born in the Spirit' (St John 3:8). For its part, the ecclesiastical administration - in compliance with the bureaucratic principle that human actions can be predicted on the basis of rules - patiently seeks to regulate the movements and restore their adherence to the prescribed canons.

The result is a 'bureaucracy of the spirit': an oxymoron which aptly expresses the tension between the fixed rules of the Church and the volatility of religious movements. The phenomenon is certainly not a novelty in the 
Roman Catholic Church. Séguy (1984), speaking of the history of monastic reforms, writes that every monastic settlement initially portrays itself as a protest against a previous form of monastic institution, while its opponents - the monastic, ecclesiastical and/or temporal authorities - try to obstruct the innovation by activating a delaying or braking mechanism - or, in some cases, both. Hervieu-Léger (2000) observes that newborn religious orders often clash with the religious authorities because they harbor utopian designs, and because their interpretation of religious truth is different from the traditional one. This clash has usually given rise to two forms of ruling: direct exclusion or an institutionally regulated compromise negotiated with the ecclesiastical authority and inscribed in the order's constitution. Generally, such a power struggle occurs each time a new community presents itself as an intensely emotional community of disciples who place the charismatic authority of their founder over other forms of authority, especially that of the orthodoxy of the relevant institution. Wittberg (2007), comparing the relations between center and periphery in the Catholic and Protestant churches, arrives at similar conclusions. The dynamics analyzed by these scholars help us to understand the gradual processes of institutionalization of many movements in the history of the Catholic Church which were accepted as communities only over time (e.g. Franciscans, Jesuits, Opus Dei). ${ }^{9}$

In order to understand these processes in the case of the NCCs, we need to bear in mind that while on one hand they experience difficulties similar to those of the traditional communities when starting out or in statu nascenti (Van Tente 1968), on the other hand the ecclesiastical world within which they arose, in the wake of Vatican Council II, was a new setting compared to the past (Ebaugh 1991; Wittberg 1996; Woodhead 2002; Wilde 2007). In particular with reference to the study of the NCCs' legitimation, there are two aspects which further complicate the analysis:

1) Forms of canonical approval are today much more numerous and differentiated than in the past. The 1983 Code introduced grades of recognition, ranging from Private Associations of the Faithful (lowest level), via Public Associations of the Faithful (intermediate level), to Institutes of Consecrated Life (highest level). ${ }^{10}$ The higher a community's degree of recognition the greater the protection afforded by the Church, but the stricter the control exercised by the latter over the community's activities. It should also be

9 Rapley $(1990,25)$ notes that the Jesuits offered the papacy a 'strike force' useful to extend papal authority, but at the price of accepting the very 'mixed' (i.e. non-monastic) hybrid form of religious order the Church had just condemned at the Council of Trent.

10 According to Canon 299 §1, Public Associations of the Faithful are: 1) Associations created by the hierarchy; 2) The same hierarchy assigns them their canonical mission in so far as the goals of such associations presuppose participation in the pastoral mission of the hierarchy; 3 ) They act on behalf of the hierarchy; 4) They are wholly subject to governance by their sacred pastors. 
borne in mind that the recognition granted to a new community may also be provisional, taking the form of ad experimentum approval.

2) The 1983 Code also established that the first authority to grant canonical recognition is the diocese (the bishop); only later do the Vatican authorities intervene (Canon 605). ${ }^{11}$ But since there are no official guidelines indicating how and when a community is fit to be recognized as a Private Association of the Faithful or to change from a Private Association of the Faithful to a Public Association of the Faithful, or from a Public Association to an Institute of Consecrated Life, it is for the bishop himself to decide whether and when this happens. There are communities that spend their entire existence without such recognition because the bishop does not regard it as appropriate. But there are also others that do not want recognition because it implies strict control by the hierarchy, which they fear would jeopardize the founding charisma of the community and suffocate its originality. This lack of regulation leaves full discretion to the bishops in deciding on an NCC's recognition, leading to numerous differences of attitude between one diocese and another. As a result, NCCs may apply for recognition from the diocese which they believe will be most favorable towards them. Finally, we must consider that the NCCs are not a priority on the ecclesiastical agenda; bishops are overburdened with more important and compelling duties in managing their dioceses, and have insufficient time to keep abreast of issues concerning the NCCs - which have still not been resolved even by scholars of canon law.

These specifications help frame the crucial question of the relationship between NCCs and the ecclesiastical authorities with greater accuracy: what innovation is more likely to arouse the reluctance of ecclesiastical authorities to grant legitimization - or, even more, full canonical recognition - to Institutes of Consecrated Life? On the basis of the bishops' interviews, I see three areas in which the innovations introduced by the NCCs pose problems: 1) the organizational-normative field; 2) the field of social welfare; and 3) the theological-liturgical field.

In the organizational-normative area, there is well-founded evidence to show that the aspects bound to create greatest reluctance in the ecclesiastical authorities are the following:

a) The cohabitation of men and women in the same building. Although men and women live in separate areas, cohabitation is a radical innovation for

11 Canon 605 states: 'The approval of new forms of consecrated life is reserved to the Apostolic See. Diocesan Bishops, however, are to endeavour to discern new gifts of consecrated life which the Holy Spirit entrusts to the Church. They are also to assist promoters to express their purposes in the best possible way, and to protect these purposes with suitable statutes, especially by the application of the general norms contained in this part of the Code.' 
the consecrated life, which is traditionally divided between male and female institutions. The greatest concern is not the risk of sexual-romantic relationships but the management of power within the community. Although tensions caused by emotional involvements have sometimes brought about the failure of a community, the most frequent problems are caused by the presence of women in positions of responsibility. As Oviedo (2010) finds in his research on gender-mixed NCCs, the question of who can and should command acquires further importance if the members of the community include priests.

b. The possibility that married people may form part of the community. Whether married couples should be included in the Institutes of Consecrated Life has been repeatedly discussed by the Vatican. To date, the answer has been that they should not, on the grounds that this inclusion would be contrary to the vows of chastity that theologically distinguish the consecrated life (Rocca 2002). Concerns of a practical nature have also caused the reluctance of the authorities to countenance associations which admit married people and families. These concerns arise not only because of possible conflicts between family and consecrated life, but also because of the risk that the community may disintegrate as a result of disagreements among the families belonging to the community (for example over the education of children).

c. The provisional nature of the vows. Some NCCs regard the commitment of their members as a privately-taken decision. Vows can be renewed year by year, and members may release themselves from them without the intervention of the external ecclesiastical authorities (Rocca 2002). This temporary nature of the vows provokes the opposition of the authorities because it contradicts the essential theological requirement of self-donation in consecration.

These innovations are to be found in all NCCs, whatever the nature of their mission, and therefore in all cells of the typology (Table 2); but not so the innovations in the field of social welfare. These mainly concern thisworldly ascetic NCCs, as the latter are in direct contact with groups that are marginal or 'disapproved' by society, as in the case of Cenacolo, Movimento Contemplativo Missionario Charles de Foucault, and Sermig (Table 2, cell 2). There are at least three aspects that may provoke resistance among the ecclesiastical authorities:

- The nature of the field activity. Disapproved of as unsuitable for the consecrated are social-work fields regarded as 'indecorous' (typically care for AIDS sufferers and spiritual support for Catholic homosexuals) or unimportant 
(e.g. aid to Gypsies or the mentally ill).

- The method of intervention. When the welfare recipients are drug addicts, alcoholics, former prisoners or former prostitutes, the attitude of the ecclesiastical authorities to the NCCs ranges from extreme indulgence (responding patiently, taking a permissive line) to the exact opposite (adopting a punitive and forcible stance). In both cases abuse and scandal may arise, so that the Church is extremely cautious about approving the methods of the communities concerned.

- The co-option of 'redeemed' social-care recipients; apart from including lay members in the governance of the community, this may give rise to unpleasant episodes, such as desertion, threats or extortion.

The most acute problems of legitimization, however, according to the bishops, are those arising from innovations in the theological and liturgical fields. These pose a direct challenge to the official teachings of the Church, and touch upon aspects of spiritual life which have always been particularly sensitive for the ecclesiastical authorities. Schematically, it is possible to identify two sets of very different problems. The first consists of initiatives in regard to ecumenism and inter-religious dialogue which the Church deems too extreme. This problem concerns the other-worldly ascetic communities (Table 2, cell 1) in particular, which are sometimes suspected by the ecclesiastical authorities of constituting outright forms of syncretism, camouflaged by the objectives of ecumenism and inter-religiosity. It would appear from official Church documents (Lettera Orationis formas 1989) that for at least the last twenty years the Congregation for the Doctrine of the Faith has been particularly concerned about communities which use psycho-physical techniques imported from the East (yoga, meditation, slow breathing etc.) in their prayers. Reassurance by the communities that these techniques have purely instrumental value does not placate the fears of the Church that such hybridization may assume doctrinal significance.

The second order of problems consists in initiatives that the Church believes to be overly focused on irrational and miraculist aspects of Catholicism. This feature especially characterizes mystical NCCs, both this-worldly and other-worldly, more generally, movements based on charismatic inspiration, which, while not forming communities in a strict sense, engage in periodic collective manifestations. The Church's suspicion of these NCCs (Table 2, cells 3 and 4) is due to the fact that they practice and disseminate liturgies which may easily turn into extreme and paroxysmal practices, such as exorcism, faith healing, and collective worship, with chanting, embracing 
and dancing. Moreover, as we have seen in Koinonia (Table 2, cell 4), the miraculous has also involved the exchange of money, leading to the blurring of boundaries in the spiritual marketplace. In this case the Church has also denounced the 'spiritual abuse' i.e. personality cults and authoritarian leadership. Added to this is the concern that these communities behave like 'Churches within the Church'. One of the most frequent accusations brought against them is that they are interested in promoting themselves rather than strengthening the Church, and that their priests are more active in the community than in their parish.

\section{Concluding Observations}

As we have seen, the difficulties connected with the ecclesiastical legitimation of the NCCs derive 1) from the potential cause of scandal which the innovations have introduced into religious life; 2) from the organizational and decision-making structure of the Church; although the Church is governed monocratically it allows for different opinions, some of which may endorse the community while others oppose it (e.g. power struggles between the bishops and the Vatican or between the bishops and especially powerful groups such as the NeoCatechumenal Way or the Legionaries of Christ); and 3) from the institutional and legal vacuum surrounding the NCCs due to a lack of canonical norms. As canon lawyers observe, a legalistic approach to such fragile phenomena risks suffocating the originality of the founding charisma.

What has not been explored in the article are the advantages that the NCCs can bring to the Church, and the consequent reasons that induce the bishops to abandon their proverbial prudence and grant rapid recognition. Analysis of the variables at work in the subtle negotiations between communities and bishops, which induce the latter to accelerate recognition or even to recognize ecclesiastically questionable communities, raises a number of questions for further research. On the basis of my field exploration, I can indicate three issues.

The first concerns the 1983 reform of the Code of Canon Law, which made bishops the prime authority in granting recognition and legitimization to NCCs. Whilst on one hand this reform has enhanced the powers of the episcopal sees with respect to Vatican authority, on the other it has brought the risk of tensions within the Church. It may happen that a bishop opposes a community because in his opinion it does not fulfill the requirements imposed by the Church, does not fit in with diocesan plans, or conflicts with his personal idiosyncrasies. In these cases, a community may 
resort to approaching a more favorable diocese, with the consequence that the same community may take root in some dioceses but not in others. The difference in attitude among bishops causes tensions and conflicts that they seek to resolve during the Episcopal Conference (of which there is one in each country); in the absence of agreement, open discussion ensues during the annual ad limina visit to the Holy See.

The second issue concerns the shortage of human resources in dioceses. The scarcity of priests is an obstacle which may weaken the bargaining power of dioceses in their negotiations with the NCCs. As mentioned at the beginning of the article, the bishops may use canonical recognition as an incentive in recruiting consecrated 'labor'. They are willing to favor communities which accept that their priests may assume responsibility for parishes, at risk of closure. Often, however, communities are reluctant to accept this proposal, given the risk that their original vocation may be impaired, so that long and delicate negotiations ensue. The shortage of priests may be so acute as to induce bishops not to suppress communities which may be questionable from an ecclesiastical point of view but which guarantee a constant flow of priests. The dilemma arises when canonical law provides for the suppression of NCCs which seriously fail to fulfill the criteria imposed, or threaten the freedom of conscience of their members.

The third issue is the social success of NCCs. Especially in communities where there is a plentiful supply of priests, the favor which they enjoy among the faithful acts as a powerful inducement for the local bishop to grant them rapid recognition, as a gesture of appreciation for their work. However, the social success enjoyed by borderline communities may also hamper sanction by bishops. The 'compulsory indulgence' which persuades the bishops to 'look away' or to 'turn a blind eye' is a result of the awareness that open opposition to the charisma of a leader venerated in a community may induce it to behave like a sect within the Church. In the case of borderline communities, it would also be fruitful to study the twofold role performed by the priests that belong to them. Whilst they are spiritual guides and dedicated members of the community, they also act as the bishop's 'guardians' of the community's orthodoxy. Subject to cross-pressures, as these priests both inspire the community's members and simultaneously temper their excesses, they are constantly exposed to the risk of being condemned as 'traitors' by one or the other party. A curious analogy is provided by football teams which infiltrate their supporters with 'stewards' given the twofold task of encouraging the fans in case of defeat and restraining disorder and violence. 
These variables constitute an extremely rich field for sociological research on the new religious communities. Indeed, the relationship between new communities and the ecclesiastical authorities is one of the most promising and interesting areas of inquiry into Roman Catholic organizations today.

\title{
Bibliography
}

\author{
Abbot, Walter M. (ed.) \\ 1966 The Documents of Vatican II. New York: American Press.
}

\section{Abbruzzese, Salvatore}

1995 La vita religiosa. Per una sociologia della vita consacrata. Rimini: Guaraldi.

\section{Anderson, Allan}

2010 Varieties, Taxonomies, and Definitions. - Allan, Anderson \& Michael Bergunder \& Andrè Droogers \& Cornelius Van der Laan (eds), Studying Global Pentecostalism, 13-29. Los Angeles: University of California Press.

\section{Baudouin, Jean \& Philippe Portier}

2002 Le mouvement catholique français à l'épreuve de la pluralité. Rennes: Presses Universitaires de Rennes.

\section{Berger, J. \& C. L. Ridgeway \& H. M. Fisek \& R. Z. Norman}

1998 The legitimation, delegitimation of power, prestige orders. - American Sociological Review 63, 379-405.

\section{Blasi, Tony \& Joseph Zimmerman}

2004 Transition from Vowed to Lay Ministry in American Catholicism. Lewiston, New York: Edwin Mellen.

\section{Bord, Richard J. \& Joseph E. Faulkner}

1983 The Charismatics: The Anatomy of a Modern Religious Movement. University Park: Pennsylvania State University Press.

Christiano, Kevin J. \& William H. Swatos \& Peter Kivisto

2008 Sociology of Religion. Plymouth: Rowman and Littlefield.

\section{Csordas, Thomas J.}

1997 The Sacred Self: Cultural Phenomenology of Charismatic Healing. Berkeley: University of California Press.

2001 Language, Charisma, and Creativity: Ritual Life in the Catholic Charismatic Renewal. New York: Palgrave MacMillan. 


\section{Della Fave, Richard}

1986 Toward an explication of the legitimation processes. - Social Forces 65 (2), 476-500.

\section{Dinges, William D.}

1987 Ritual Conflict as Social Conflict: Liturgical Reform in the Roman Catholic Church. - Sociology of Religion 48 (2), 138-57.

\section{Diotallevi, Luca}

2001 Il rompicapo della secolarizzazione. Caso italiano, teorie americane e revisione del paradigma della secolarizzazione. Soveria Mannelli: Rubbettino.

Ebaugh, Helen R.

1991 The Revitalization Movement in the Catholic Church: The Institutional Dilemma of Power. - Sociological Analysis 32 (1), 1-12.

Eisenhardt, Kathleen M. \& Melissa E. Graebner

2007 Theory Building from Cases: Opportunities and Challenges. - Academy of Management Journal 50 (1), 25-32.

\section{Hervieu-Léger, Danièle}

2000 Religion as a Chain of Memory. Rutgers: Rutgers University Press.

\section{Johnson, Cathryn \& Timothy J. Dowd \& Cecilia L. Ridgeway}

2006 Legitimacy as a Social Process. - Annual Review of Sociology 32, 53-78.

\section{Kalberg, Stephen}

2001 Should the Dynamic Autonomy of Ideas Matter to Sociologists? Max Weber on the Origin of Other-Worldly Salvation Religions and the Constitution of Groups in American Society Today. - Journal of Classical Sociology 1 (3), 291-328.

\section{Landron, Olivier}

2004 Les Communautés nouvelles. Nouveaux visages du catholicisme français. Paris: Éd. du Cerf.

\section{Marzano, Marco}

2009 Cattolicesimo magico. Un'indagine etnografica. Milano: Bompiani.

\section{Neitz, Mary J.}

1987 Charisma and Community: A Study of Religious Commitment within the Charismatic Renewal. New Brunswick (NJ): Transaction.

\section{Oviedo, Lluis T.}

2010 Approccio alla realtà delle nuove fondazioni - R. Fusco \& G. Rocca (eds), Nuove forme di vita consacrata, 163-77. Roma: Urbaniana University Press. 


\section{Pace, Enzo}

1983 Asceti e mistici in una società secolarizzata. Venezia: Marsilio.

\section{Poloma, Margaret M.}

1989 The Assemblies of God at the Crossroads: Charisma and Institutional Dilemmas. Knoxville: University of Tennessee Press.

\section{Powell, Walter \& Paul DiMaggio (eds)}

1991 The New Institutionalism in Organizational Analysis. Chicago: University of Chicago Press.

\section{Rapley, Elizabeth}

1990 The devotes: Women and church in seventeenth century France. Montreal: McGill Queens University Press.

\section{Riis, Ole}

1989 The Role of Religion in Legitimating the Modern Structuration of Society. - Acta Sociologica 32 (2), 137-53.

\section{Rocca, Giancarlo}

2002 Nuove forme di vita consacrata. - Vita consacrata 38 (6), 563-75.

\section{Roldàn, Verònica}

2009 Il rinnovamento carismatico cattolico. Milano: FrancoAngeli.

Scott, Richard W. \& John W. Meyer

1991 The Organization of Societal Sectors: Propositions and Early Evidence. - Walter Powell \& Paul DiMaggio (eds), The New Institutionalism in Organizational Analysis, 108-40. Chicago: University of Chicago Press.

\section{Séguy, Jean}

1984 Une sociologie de sociétés imaginaires: monachisme et utopie. - Annales 2, 328-59.

\section{Seidler, John \& Katherine Meyer}

1989 Conflict and Change in the Catholic Church. Rutgers: Rutgers University Press.

\section{Van Tente, $M$.}

1968 Nuove Comunità. - G. Pelliccia \& G. Rocca (eds) Dizionario degli Istituti di perfezione. Roma: Edizioni paoline.

\section{Walker, Henry A. \& George M. Thomas \& Morris Zelditch}

1986 Legitimation, endorsement, and stability. - Social Forces 64 (3), 620-43.

\section{Weber, Max}

1978 Economy and Society. An Outline of Interpretative Sociology. (Edited by Guenther Roth \& Claus Wittich.) Berkeley: University of California Press. 


\section{Wilde, Melissa}

2007 Vatican II. A Sociological Analysis of Religious Change. Princeton: Princeton University Press.

Wilkinson, Michael \& Peter Althouse

2010 Varieties of Prayer in the Pentecostal Movement. Oral presentation. -ASR 72nd annual meeting, 12-16 August, Atlanta.

\section{Wittberg, Patricia}

1996 Real Religious Communities: A Study of Authentication in New Roman Catholic Religious Orders. - Religion and the Social Order 6, $149-74$.

1997 Deep Structure in Community Cultures: The Revival of Religious Orders in Roman Catholicism. - Sociology of Religion 58 (3), 239-59.

2007 Orders and Schisms on the Sacred Periphery. - James A. Beckford \& Nicholas J. Demerath (eds), The Sage Handbook of Sociology of Religion, 323-44. London: Sage.

\section{Woodhead, Linda}

2002 Christianity. - Linda Woodhead (ed.) Religions in the modern world, 153-81. London: Routledge.

Yin, R.

1994 Case Study Research: Design and Methods. London: Sage.

\section{Zelditch, Morris}

2001 Processes of Legitimation: Recent Developments, New Directions. Social Psychology Quarterly 64 (1), 4-17. 


\section{Appendix: Tables}

\begin{tabular}{|c|c|c|c|c|c|}
\hline 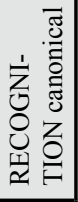 & 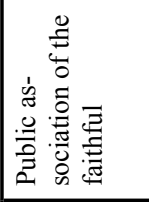 & 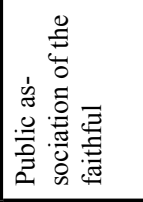 & 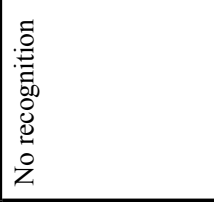 & 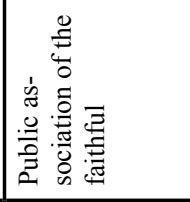 & 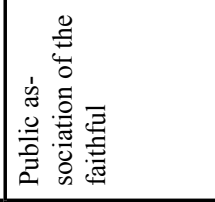 \\
\hline 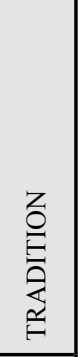 & 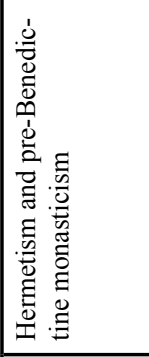 & 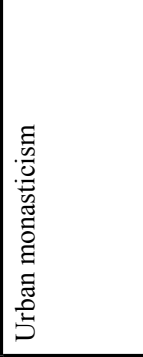 & 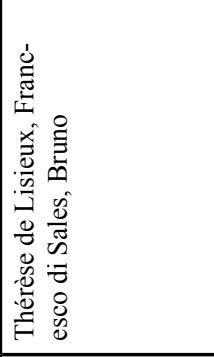 & 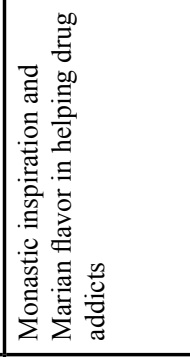 & 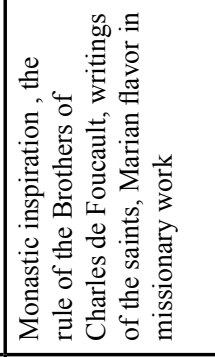 \\
\hline 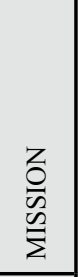 & 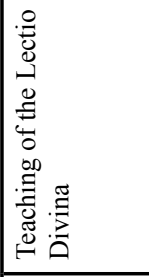 & 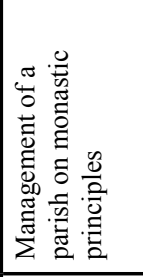 & 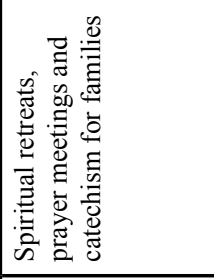 & 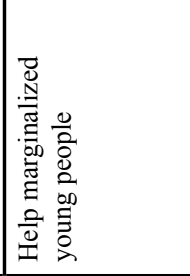 & 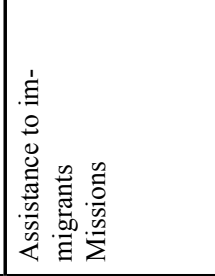 \\
\hline 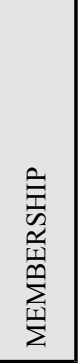 & 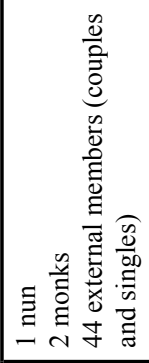 & \begin{tabular}{|l}
$n$ \\
0 \\
0 \\
0 \\
0 \\
0 \\
0 \\
$\vdots$ \\
$m$ \\
$m$
\end{tabular} & 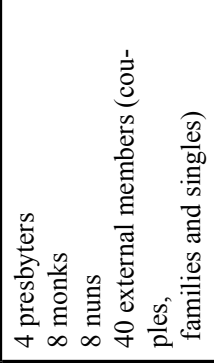 & 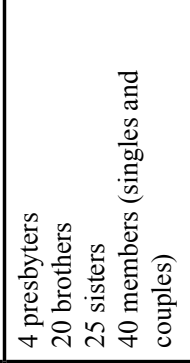 & 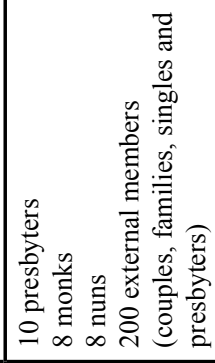 \\
\hline 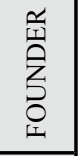 & 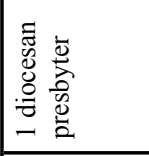 & 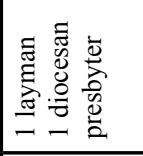 & 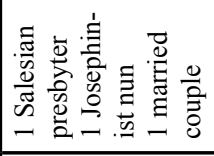 & 䒠 & 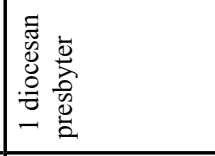 \\
\hline 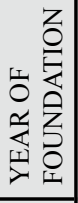 & $\stackrel{2}{\Omega}$ & $\stackrel{n}{2}$ & \begin{tabular}{l}
$\infty$ \\
\multirow{2}{2}{}
\end{tabular} & $\begin{array}{l}\infty \\
\stackrel{\infty}{=}\end{array}$ & ปั \\
\hline$\underset{z}{\sum}$ & 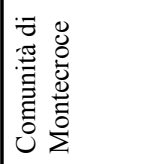 & 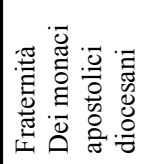 & 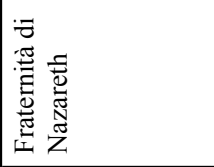 & $\begin{array}{l}0 \\
0 \\
0 \\
\tilde{0} \\
0 \\
0\end{array}$ & 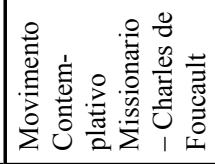 \\
\hline
\end{tabular}




\begin{tabular}{|c|c|c|c|c|c|}
\hline 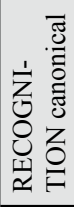 & 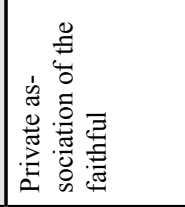 & 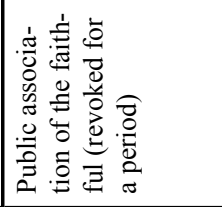 & 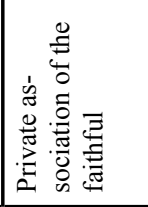 & 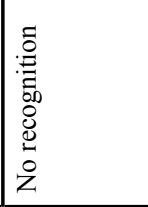 & 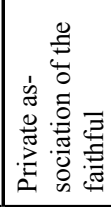 \\
\hline 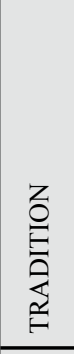 & 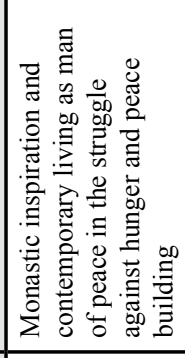 & 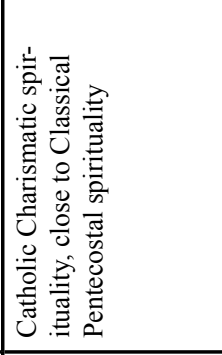 & 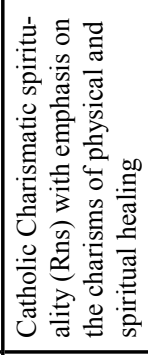 & 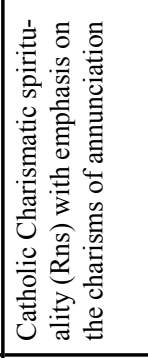 & 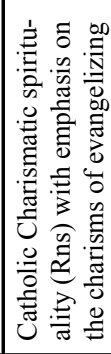 \\
\hline $\begin{array}{l}z \\
0 \\
v \\
\tilde{n} \\
\Sigma\end{array}$ & 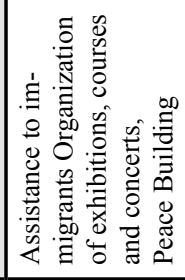 & 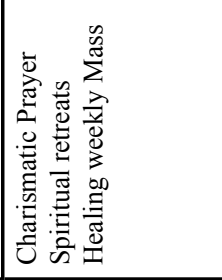 & 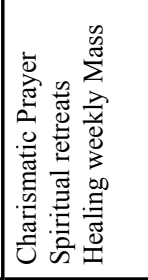 & 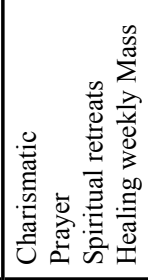 & 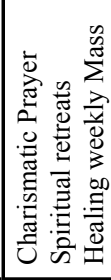 \\
\hline 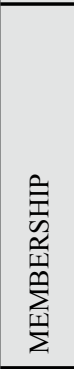 & 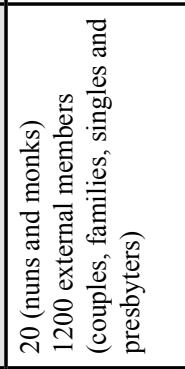 & 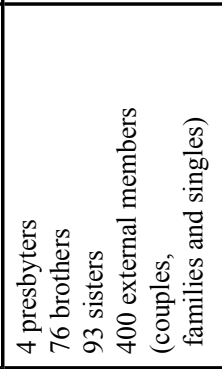 & 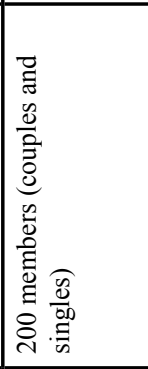 & 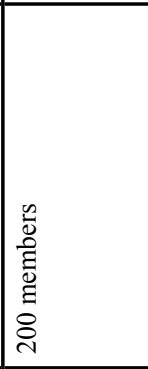 & 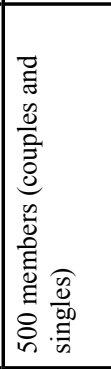 \\
\hline 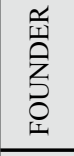 & 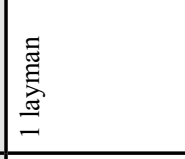 & 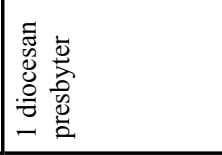 & 壱 & 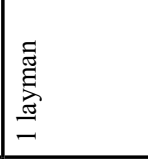 & 䓌 \\
\hline 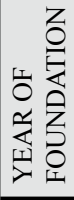 & 孛 & 今ิ & $\mid \begin{array}{c}2 \\
\end{array}$ & 亏ू & $\stackrel{2}{2}$ \\
\hline$\sum_{z}^{\infty}$ & 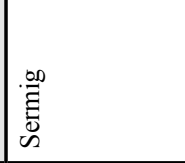 & 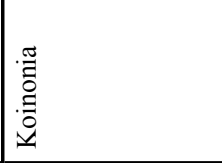 & 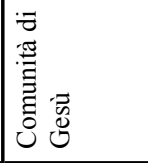 & 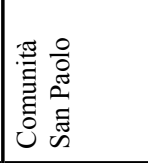 & 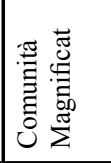 \\
\hline
\end{tabular}


Table 2: A typology of NCCs

Relationship with the world

\begin{tabular}{|c|c|c|}
\hline & Other-Worldly & This-Worldly \\
\hline ASCETICISM & $\begin{array}{l}1 \\
\text { Other-Worldly } \\
\text { Ascetic Communities }\end{array}$ & $\begin{array}{l}2 \\
\text { This-Worldly } \\
\text { Ascetic Communities }\end{array}$ \\
\hline MYSTICISM & $\begin{array}{l}3 \\
\text { Other-Worldly } \\
\text { Mystical Communities }\end{array}$ & $\begin{array}{l}4 \\
\text { This-Worldly } \\
\text { Mystical Communities }\end{array}$ \\
\hline
\end{tabular}


